\title{
Pengasuhan Keluarga terhadap Perkembangan Karakter Disiplin Anak Usia Dini
}

\author{
Fadilah Utami ${ }^{1 凶}$, Iis Prasetyo ${ }^{2}$ \\ Pendidikan Luar Sekolah, Universitas Negeri Yogyakarta \\ DOI: 10.31004/obsesi.v5i2.985
}

\begin{abstract}
Abstrak
Perkembangan karakter disiplin dipengaruhi oleh pola pengasuhan yang diterima anak dari lingkungan keluarga khususnya orang tua, namun langkah preventif orang tua dalam menumbuhkan karakter disiplin anak masih minim. Tujuan dilakukannya penelitian ini adalah untuk menganalisis dan mengetahui hubungan pola pengasuhan keluarga terhadap pembentukan karakter disiplin anak. Metode pengambilan data menggunakan metode kajian pustaka yang dilakukan dengan langkah-langkah yaitu mencatat semua tentang masalah penelitian, memadukan semua temuan, menganalisis setiap temuan, lalu mengkritisi serta memberi gagasan. Hasil penelitian menunjukkan bahwa terdapat hubungan pengasuhan yang diberikan orang tua terhadap pembentukan karakter disiplin anak. Penelitian ini menunjukkan bahwa perkembangan karakter disiplin anak dipengaruhi oleh pola pengasuhan yang diterima dari orang tua. Bentuk pengasuhan yang yang beragam memberikan pengaruh yang berbeda pula terhadap anak. Diketahui bahwa masing-masing gaya pengasuhan yaitu pengasuhan otoriter, pengasuhan demokratis, dan pengasuhan permisif yang diterapkan dalam keluarga memengaruhi perkembangan anak dimasa depan.
\end{abstract}

Kata Kunci: karakter disiplin, pengasuhan keluarga, anak usia dini

\begin{abstract}
The development of disciplined character is influenced by the parenting patterns that children receive from the family environment, especially parents. The purpose of this research is to analyze and determine the relationship between family parenting and the character building of children's discipline. The data collection method uses the literature review method which is carried out in steps, namely recording all the research problems, combining all findings, analyzing each finding, then criticizing and giving ideas. The results showed that there was a relationship between parenting and the character building of children's discipline. This study shows that the development of children's disciplinary character is influenced by the parenting patterns received from parents. Different forms of care have different effects on children. It is known that each of the parenting styles, namely authoritarian parenting, democratic parenting, and permissive care that is applied in the family affects the child's future development.
\end{abstract}

Keywords: character, family care, early childhood

Copyright (c) 2020 Fadilah Utami, Iis Prasetyo

Corresponding author :

Email Address: fadilahutami.2018@student.uny.ac.id (Depok, Sleman, Yogyakarta)

Received 21 December 2020, Accepted 10 January 2021, Published 13 January 2021 


\section{PENDAHULUAN}

Pendidikan selalu menjadi dasar dari segala upaya untuk mencapai suatu hal yang dimulai dari sejak anak dilahirkan hingga akhir hayat. Pendidikan utama pertama kali didapat anak bermula dari lingkungan keluarga ataupun orang tuanya. Namun, dewasa ini banyak orang tua abai terhadap pendidikan anak-anaknya. Padahal perhatian dan dukungan orang tua terhadap perkembangan anak sangatlah dibutuhkan sebagai bentuk dan upaya memberikan pendidikan utama dan lebih baik di usia awal pertumbuhannya. Saat ini banyak lembaga-lembaga penitipan anak yang membuat peran orang tua tergantikan oleh orang lain sehingga intensitas orang tua menjadi berkurang dalam mendampingi tumbuh kembang anak. Kehidupan dan kesibukan orang tua memengaruhi interaksinya dengan anak. Hal itu tentu harus menjadi sebuah perhatian orang tua karena pendidikan yang didapat kelak akan memengaruhi kehidupannya di lingkungan dan masa depan.

Anak adalah calon masa depan, sebagai generasi penerus yang membutuhkan dukungan, pembinaan, perhatian dan pengembangan yang optimal dari sejak usia dini (Husnul, 2016), sehingga harus selalu mendapat perhatian dan pendampingan. Erikson mengatakan bahwa tahap kehidupan seseorang dibentuk atas berbagai pengaruh dan interaksi sosial yang diterimanya sehingga menjadikan dia sebagai manusia yang matang secara fisik dan psikologis (Erik, 2010). Pendidikan, lingkungan, pengalaman dan orang tua adalah faktor-faktor yang memberi pengaruh besar terhadap terbentuknya nilai kepribadian serta karakter bagi anak.

Dunia yang semakin maju memengaruhi bagaimana kebudayaan dalam kehidupan manusia berkembang. Sejalan dengan berkembangnya teknologi dan kebudayaan berbagai permasalahan muncul akibat meluasnya kebiasaan-kebiasaan baru yang diterima masyarakat akibat berkembangnya teknologi dan budaya yang muncul (Mastura, 2020). Televisi adalah salah satu bentuk dari berkembangnya teknologi. Televisi sebagai media hiburan turut mengambil andil dalam memengaruhi budaya masyarakat. Anak-anak mendapat imbas dan memengaruhi perkembangannya setelah melihat tayangan televisi. Begitu banyak pengaruh buruk yang didapat anak dari melihat tayangan di televisi mulai dari masalah kesehatan hingga bahkan masalah perkembangan psikologis. Hal ini membuktikan bahwa peran orang tua sebagai pendamping perkembangan, membimbing dan memberi pemahaman tentang hal baik atau buruk amat sangat dibutuhkan oleh anak.

Orang tua adalah orang terdekat bagi anak yang mempunyai peran dan tanggung jawab yang besar terhadap perkembangan dan tumbuh kembangnya (Lasota, 2015). Lingkungan keluarga merupakan ruang lingkup utama untuk anak dalam menjalani proses berkembang dan belajar bagi anak. Dalam lingkungan keluarga anak akan belajar mengenai nilai, sikap, norma dan kepercayaan budaya, serta kebiasaan-kebiasaan dalam keluarga sehingga anak akan tumbuh menjadi manusia yang memiliki sikap positif dan mulia dalam bertindak dilingkungan yang lebih luas (Munch. L.E.L, 2016). Suyadi (2014) mengatakan bahwa pembinaan yang diberikan kepada anak berupa rangsangan pendidikan akan membantunya bertumbuh sehingga memiliki kesiapan untuk melanjutkan pendidikan yang lebih tinggi. Nilai-nilai yang ditanamkan kepada anak sejak usia dini jelas memberikan pengaruh untuk menjadikannya manusia yang lebih bernilai dan memiliki sikap yang positif serta mulia dimasa sekarang dan yang akan datang.

Karakter adalah tabiat/tingkah laku, kepribadian, watak individu yang terbentuk dari internalisasi berbagai kebiasaan diyakini akan memengaruhi cara pandang, bersikap, berpikir dan bertindak (Tabi'in, 2017). Pola asuh dan pengasuhan yang dialami dan diterima seorang anak akan memengaruhi hal-hal tersebut yang membawa banyak dampak dimasa mendatang. Karakter seseorang yang paling memengaruhi kehidupan adalah karakter kedisipilinan. Kedisiplinan adalah karakter yang unggul yang akan memberikan pengaruh bagi kehidupan seorang siswa dalam mengarungi kehidupannya (Megawangi, 2004). 
Dalam pendidikan holistik, beruntunglah manusia yang berkarakter karena mereka adalah manusia yang seluruh dimensi kehidupannya berkembang secara menyeluruh dan utuh (holistik), yang menjadikannya menjadi manusia yang beruntung holy (suci dan bijak). Whole adalah akar kata holy yang memiliki arti menyeluruh, dengan demikian arti holy man adalah manusia yang seluruh dimensinya berkembang secara utuh dan menyeluruh (Tabi'in, 2017).

Disiplin adalah sebuah tindakan yang menunjukkan kepatuhan, tertib, hormat serta patuh pada keputusan, peraturan, ketentuan dan perintah yang berlaku. Disiplin adalah aset penting untuk menghadapi berbagai tantangan kehidupan dan berbagai masalah yang nantinya akan dihadapi bagi diri sendiri dan juga orang lain. Kedisiplinan menjadi sebuah kunci sukses mengatasi hal tersebut. Selain itu, terdapat hal lain yang membuat mengapa menanamkan dan menumbuhkan karakter disiplin kepada anak sangat penting dilakukan, seperti: belajar lebih konsisten, mengerti akan pentingnya waktu, mengajarkan kejujuran, meningkatkan rasa tanggung jawab, hidup teratur dan sehat.

Disiplin merupakan salah satu sikap moral yang tidak otomatis muncul sejak anak dilahirkan, tetapi dibentuk oleh lingkungan melalui pola asuh orang tua terhadap anak, guru, serta orang dewasa lain yang ada disekitarnya. Faktor yang memengaruhi disiplin diantarnya adalah faktor intern (dalam), ekstern (luar) baik itu sekolah, maupun masyarakat/keluarga. Julie Adrews dalam Sheila Ellison dan Barbara Barnet mengatakan "Dicipline is a from of life training that, once experienced and when practiced, develops an individual's ability to control themselves". Disiplin merupakan suatu bentuk aktivitas manusia dalam memenuhi kebutuhan fisiknya dalam kehidupan, dan merupakan pengalaman yang dilalui dan akan dilakukan sehingga seseorang dapat mengembangkan kemampuannya dalam mawas diri dan mengerti dirinya (Julie, 1996).

Lingkungan memengaruhi dalam proses perkembangan karakter kedisiplinan anak adalah sebuah proses internalisasi dan eksternal dan juga merupakan proses konstruktif yang memberi perubahan secara eksplisit dan implisit pada anak sehingga memengaruhi aspek perkembangannya baik kognitif, afektif, sosial dan emosionalnya. Lingkungan yang memengaruhi perkembangan karakter disiplin anak salah satunya adalah keluarga. Peran keluarga khususnya orang tua memegang peranan inti dalam perkembangan karakter disiplin anak usia dini. Pada tahap ini juga pengenalan awal akan kedisiplinan dapat ditanamkan di usia yang muda. Pendidikan awal dan utama yang diterima anak adalah pendidikan keluarga yang didapatnya sebagai lingkungan luar akan memengaruhi pembentukan karakter kepribadian dan pembinaan mental (Sobur, 1991:21). Undang-undang No 23 Tahun 2002 pasal 26 tentang perlindungan anak menyatakan bahwa orang tua memiliki kewajiban dan tanggung jawab kepada anak untuk memelihara, mengasuh, melindungi dan mendidik anak, menumbuh kembangkan sesuai dengan minat, bakat dan kemampuannya serta mencegah anak dari perkawinan pada usia anak-anak.

Penerapan nilai-nilai disiplin bagi anak diajarkan orang tua dengan kebiasaankebiasaan baik, aturan dan pola asuh, sehingga anak terbiasa dan mengerti tentang disiplin. Pengasuhan memiliki beberapa gaya pengasuhan menurut Diana Baumbrid dalam (Bibi, F, 2013) yaitu pengasuhan otoriter (authoritarian), pengasuhan otoritatif (authoritative) dan permisif dengan konsep persyaratan dan tanggapan (permissive with these concepts of responsiveness and demandingness). Penerapan nilai-nilai kepatuhan dan kedisiplinan pada anak dan keberhasilannya dilihat dari bagaimana pola atau gaya pengasuhan orang tua. Selain itu karakteristik anak, sosialisasi anak dan orang tua, komunikasi, budaya dan kebiasaan yang ditanamkan oleh orang tua juga ikut memengaruhi karakter disiplin pada anak.

Berbagai pola dan tipe pengasuhan penting untuk diperhatikan oleh orang tua untuk mendukung keberhasilan dan perkembangan anak usia dini seperti yang dinyatakan oleh Mukarromah et al., (2021); Irma, (2016); A, (2017); Yenni, (2017); Asiatik et al., (2017); Rahmi \& Riana, (2018). Pola asuh adalah strategi orang tua dalam merawat, membimbing, mendidik, melindungi, sosialisasi, pendisiplinan anak yang merupakan proses anak dalam berperilaku 
agar diterima dilingkungan sosial. Berbagai penelitian-penelitian sebelumnya tentang pola asuh dan kultur pengasuhan keluarga memiliki andil dan kontribusi yang cukup berpengaruh terhadap perkembangan anak usia dini termasuk perkembangan disiplin anak.

Pembentukan karakter disiplin yang baik perlu dilakukan sejak usia dini, dengan cara dan pola pengasuhan yang tepat maka karakter disiplin yang ditanamkan akan sangat berguna bagi anak sebagai bekal perkembangannya dimasa mendatang (Mohammad et al., 2020). Lingkungan keluarga sebagai lingkungan pertama di mana anak mendapatkan pendidikan dan pola pengasuhan yang tepat adalah sebuah proses yang dapat dibentuk sesuai dengan kaidah yang sesuai. Pola pengasuhan yang berbeda-beda tentunya juga akan menentukan karakter yang berbeda pula kepada anak. Misalnya, orang tua yang memberikan bentuk disiplin terhadap aturan dengan cara membimbing anak namun tidak mengatur, dan menghargai anak (demokratif). Apakah terdapat dampak hubungan dari pengasuhan yang diberikan orang tua terhadap pembentukan karakter anak, dan apakah bentuk-bentuk pengasuhan lainnya sama dengan pengasuhan lainnya memberikan dampak yang sama terhadap anak. Dengan mengerti berbagai pengetahuan dan informasi tentang pola pengasuhan yang ada maka orang tua dapat memberikan pengasuhan yang lebih baik kepada anak sehingga dapat meningkatkan pengembangan karakter disiplin pada anak-anak.

Untuk mengetahui bagaimana dan adakah pengaruh pola pengasuhan anak usia dini terhadap karakter disiplin anak maka penelitian dengan kajian pustaka ini diharapkan dapat menjadi referensi bagi para orang tua untuk memilih dan menerapkan pola pengasuhan yang tepat untuk diberikan kepada anak.

\section{METODOLOGI}

Dalam penelitian ini penulis menggunakan metode kepustakaan atau kajian pustaka. Kajian pustaka atau kepustakaan merupakan bagian yang terpenting dari berbagai keseluruhan langkah-langkah metode penelitian. Metode dalam penelitian ini dimulai dengan mencatat semua tentang masalah penelitian yang diangkat, lalu memadukan semua temuan dengan masalah yang dibahas, selanjutnya menganalisis setiap temuan, lalu mengkritisi serta memberi gagasan.

Metode pengambilan data menggunakan metode kajian pustaka yang dilakukan dengan langkah-langkah yaitu mencatat semua tentang masalah penelitian, memadukan semua temuan, menganalisis setiap temuan, selanjutnya memberikan gagasan. Zherly \& Farida (2019) menjelaskan bahwa kajian pustaka (library research) adalah bagian dari kegiatan penelitian yang dilakukan dengan mengumpulkan data-data atau didasarkan pada karyakarya tulis ilmiah yang berhubungan dengan objek penelitian atau kegiatan penelitian yang pengumpulan datanya bersifat kepustakaan, kemudian telaah dilakukan untuk menyelesaikan, memecahkan suatu masalah secara mendalam terhadap bahan-bahan pustaka yang relevan.

Penelitian dengan metode kepustakaan atau kajian pustaka adalah penelitian yang termasuk pada penelitian deskriptif, penelitian deskriptif berfokus pada suatu sistematis tentang fakta-fakta yang diperoleh ketika penelitian dilakukan (Anwar, 2016). Metode pengumpulan data dengan penelitian kajian pustaka diambil dari sumber data. Sumber data adalah subjek dari mana sebuah data didapat, banyak sumber data yang dapat digunakan yaitu; buku-buku, referensi statistik, jurnal ilmiah, hasil penelitian dalam bentuk tesis, skripsi ataupun disertasi, internet dan berbagai sumber lainnya yang relevan.

Penelitian ini menggunakan metode kepustakaan dilakukan dengan alasan bahwa metode kajian pustaka merupakan tahapan yang harus dilewati dalam melakukan penelitian. Dengan melakukan studi pendahuluan terlebih dahulu untuk memahami dan mengetahui gejala dan fenomena yang sedang berkembang dimasyarakat, lalu hasil dari penelitian kepustakaan dapat dipercaya untuk menjawab masalah penelitian, dan permasalahan dalam penelitian hanya dapat diketahui jawabannya dengan menggunakan kajian kepustakaan (Zherly \& Farida, 2019). Riset pustaka dilakukan untuk memanfaatkan berbagai sumber 
pustaka dalam memperoleh data penelitian sehingga kegiatan riset lapangan tidak lagi diperlukan.

Sebelum melakukan telaah berbagai sumber-sumber ilmiah pertama kali yang harus dilakukan oleh peneliti adalah mencatat setiap temuan yang berhubungan dengan masalah penelitian yang didapat dalam berbagai literatur dan sumber ilmiah ataupun berbagai datadata terbaru yang berhubungan dengan masalah penelitian. Selanjutnya segala hasil temuan dipadukan lalu dianalisis kelebihan dan kekurangan dalam tiap-tiap wacana yang dibahas dan dilakukan kolaborasi dengan pemikiran baru terhadap masalah penelitian. Hasil analisis tersebut lalu diberikan gagasan dan komentar dalam wacananya sehingga menghadirkan temuan baru dalam mengolaborasikan pemikiran-pemikiran terhadap masalah penelitian (Mirshad, 2014). Analisis terhadap data kajian tersebut dilakukan dengan analisis isi (content analysis) atau disebut juga penelitian pembahasan mendalam terhadap isi informasi.

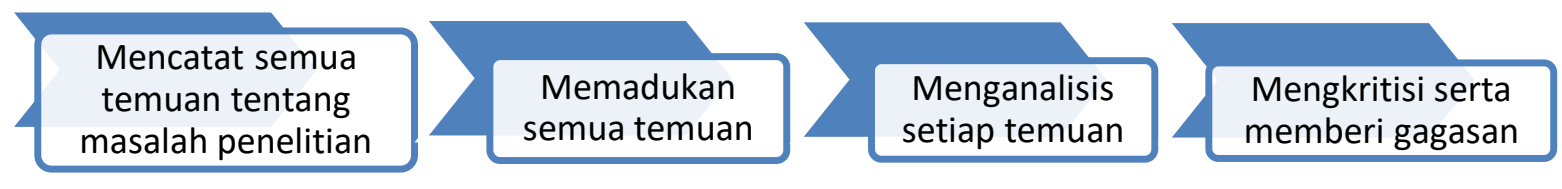

Gambar 1. Langkah-langkah penelitian kajian pustaka

\section{HASIL DAN PEMBAHASAN}

\section{Gaya Pengasuhan Keluarga terhadap Perkembangan Karakter Disiplin Anak Usia Dini}

Gaya pengasuhan melibatkan berbagai interaksi antara anak dan orang tua dapat menentukan bagaimana perkembangan moral anak selanjutnya. Strategi dalam mendidik oleh orang tua disebut juga dengan gaya pengasuhan, gaya pengasuhan turut berkontribusi dalam perkembangan anak selanjutnya. Kajian ini telah dilakukan oleh Walker \& Hennig, (2010). Sama halnya dengan karakter disiplin yang ada pada anak juga dipengaruhi oleh gaya pengasuhan orang tua. Dahlena (2019) pada penelitiannya tentang pola asuh orang tua dalam meningkatkan disipilin anak menunjukkan bahwa terdapat pengaruh pola asuh orang tua terhadap kedisiplinan anak.

Setiap keluarga memiliki bentuk pengasuhan yang berbeda-beda. Interaksi dan komunikasi dalam keluarga menjadikan berbedanya pola asuhan dalam setiap keluarga. Pola asuh adalah sikap orang tua dalam berinteraksi kepada anak. Pola asuh menurut Kohn dalam (Krisnawaty, 2010) berkaitan dengan interaksi orang tua dalam menerapkan atau memberikan kegiatan pengasuhan mengartikan bahwa orang tua memberikan aturan-aturan, hukuman, apresiasi, keberadaan dan kekuasaan serta memberikan bentuk kasih sayang dan perhatian dan tanggapan kepada anaknya. Hurlock (1997:59) menyampaikan bahwa pola asuh sama halnya dengan bentuk kedisiplinan. Disampaikan pula bahwa menerapkan berbagai nilai dalam keluarga merupakan bentuk dari kedisiplinan.

Disiplin adalah cara masyarakat mengajarkan perilaku moral kepada ada sehingga dapat diterima oleh kelompok. Karakter disiplin yang dimiliki oleh anak memberikan pemahaman kepadanya tentang baik dan buruk serta memberikan dorongan kepadanya agar berperilaku sesuai dengan standar yang berlaku dimasyarakat. Pola ataupun sikap orangtua kepada anak akan memberi pengaruh terhadap bentuk perilaku anak. Bentuk perilaku tersebut antara lain yaitu kompetensi sosial, emosional dan intelektual anak.

Tiga macam bentuk pola asuh orang tua. Pertama, sistem otoriter adalah suatu bentuk pola asuh yang ketat dan menuntut kepada anak untuk mematuhi peraturan-peraturan yang dibuat. Bentuk pola asuh otoriter akan membentuk anak sulit untuk menyesuaikan diri, takut, minder, dan memiliki kemampuan komunikasi yang lemah. Ketakutan tersebut ternyata menjadi pengaruh kepada anak. Kedua, sistem permisif merupakan suatu bentuk pola asuh yang membebaskan anak dalam pengambilan keputusan dari kontrol orang tua. Pola asuh permisif dapat disebut juga dengan pola asuh yang liberal, di mana orang tua memberikan 
kebebasan kepada anaknya untuk bertindak dan berperilaku sesuai keinginan anak (Martaniah, 1964). Orang tua dengan tipe permisif sedikit memberi intervensi dan teguran serta bimbingan kepada anak dan dapat dibilang kurang berperan dalam kehidupan anak. Ketiga, sistem otoritatif adalah pola pengasuhan yang positif, di mana orang tua turut memberikan bimbingan kepada anak dalam memilih dan melakukan sebuah tindakan. Orang tua secara terbuka memberikan kesempatan kepada anak-anaknya untuk mandiri, dan terbuka dalam menyampaikan berbagai pikiran dan pendapatnya. Pengasuhan ini disebut juga dengan pola asuh demokratis. Orang tua berperan sebagai pemberi arahan dan masukan yang tidak mengikat dan bersifat objektif, penuh dengan kasih, perhatian namun tetap memiliki kontrol terhadap anak-anaknya sehingga orang tua dapat menyesuaikan dengan kemampuan anaknya.

Pada penelitian terbaru yang dilakukan oleh Lia \& Arif (2021) menyatakan bahwa keberadaan nenek ataupun kakek yang turut serta membesarkan cucu ternyata juga memberikan pengaruh pada pembentukan karakter disiplin yang baik pada anak. Masingmasing nenek menerapkan pola pengasuhan pada berbagai kebiasaan dan karakter disiplin pada cucunya. Pola pengasuhan yang diterapkan adalah otoriter, permisif dan otoratif yang diberikan dengan metode penjelasan, contoh dan pembiasaan sedari dini.

Bentuk pola asuh yang diterapkan oleh orang tua dapat meningkatkan atau bahkan sama sekali tidak memberikan karakter disiplin pada anak. Ida dalam penelitiannya tentang pola asuh disebutkan bahwa orang tua dalam menerapkan karakter disiplin pada anak mengalami kendala berupa kendala intern (dalam keluarga) seperti, komunikasi dan interaksi yang kurang baik karena kesibukan orang tua dalam meluangkan waktu untuk menerapkan nilai-nilai kedisiplinan, sedangkan kendala ekstern (lingkungan luar) berupa perkembangan zaman dalam bentuk teknologi yakni gawai atau telepon genggam, televisi dan pergaulan (Ida, 2019).

Pola asuh yang diterapkan orang tua memiliki hubungan yang erat terhadap berkembangnya karakter disiplin anak, dikatakan dalam penelitiannya Rahmi \& Riana (2018) menunjukkan nilai yang signifikan tentang pengaruh pola asuh orang tua dalam meningkatkan karakter disiplin anak. Disebutkan pula bahwa pola asuh yang diberikan oleh orang tua dipengaruhi oleh oleh pengalaman orang tua dalam mendidik dan merawat anak serta pendidikan orang tua akan memberikan pengaruh kepada orang tua dalam melakukan pengasuhan kepada anaknya. Selain itu lingkungan juga memengaruhi bentuk pengasuhan yang orang tua berikan kepada anaknya, selanjutnya budaya juga memberikan dampak yang cukup banyak dalam pola pengasuhan orang tua. Sering sekali orang tua mengikuti bagaimana pola asuh yang diterapkan di masyarakat, serta kebiasaan-kebiasaan tertentu yang dianggap berhasil dalam menerapkan nilai-nilai ataupun norma yang diakui.

Bentuk pola pengasuhan yang diberikan orang tua kepada anak dengan serta merta memengaruhi bagaimana anak berkembang. Pola pengasuhan yang cenderung memberikan kebebasan (permisisve), dan membiarkan anak akan membuat anak tidak memahami bagaimana harus bersikap yang baik dan timbulnya karakter disiplin. Kebebasan yang diberikan oleh orang tua dapat menyebabkan anak tidak patuh, menuntut, memberontak, impulsif, bergantung kepada orang lain, serta menimbulkan perilaku anti sosial (Steinberg, L., Blatt-Eisengart, I., \& Cauffman, 2006). Dalam penelitiannya Hapsari (2016) dalam Nauli, V. A., Karnadi, K., \& Meilani (2019) memaparkan bahwa anak belajar tentang bagaimana bentuk benar dan salah dimulai dengan hal-hal yang sederhana di dalam kehidupan sehari-hari. Saat anak melakukan kesalahan, hendaknya anak diberikan penjelasan mengapa perbuatan yang dilakukan salah, teguran dan hukuman serta pemahaman tentang perilakunya yang kurang sesuai akan berdampak tidak baik bagi masa depannya. Begitu juga sebaliknya ketika anak melakukan kebaikan atau perbuatan baik dan benar, hendaknya orang tua memberitahu alasan kenapa hal tersebut benar dan diberikan apresiasi terhadap perbuatan baiknya. Hal tersebut tentu akan memberikan dampak yang baik bagi perkembangan karakter disiplin anak dalam menerapkan nilai-nilai baik di dalam kehidupannya. 
Pola pengasuhan yang dianggap paling baik dan kondusif bagi perkembangan anak di mana orang tua membentuk kemandirian kepada anak namun tetap membimbing dan mengarahkan anak serta tetap menerapkan batasan dan kendali atas keputusan yang diambil oleh anak (demokratis). Orang tua dengan tipe pola asuh demokratis membentuk karakter anak dengan baik tanpa merusak kemandirian, kepribadian pada anak (Karmakar, 2015). Menurut Chatib (2012) dikatakan bahwa anak usia dini belajar menerapkan nilai-nilai dan melaksanakan peraturan serta karakter kedisiplinan dengan cara melihat atau mencontoh lebih dahulu learning by doing and learning by example. Anak akan terbiasa disiplin bila orang tua juga menerapkan nilai disiplin pada dirinya serta juga memberikan pemahaman dan arahan mengenai nilai-nilai kedisiplinan pada diri anak.

Pola pengasuhan otoriter yang diberikan kepada anak akan memberikan dampak lemahnya anak dalam berkomunikasi dan menyampaikan pendapat dan mengungkapkan apa yang dirasakan karena merasa takut kepada orang tua (Juharta, dkk, 2015). Anak akan sulit untuk bersosialisasi dan berkomunikasi kepada orang lain dan sulit untuk mengerti dan memahami kemauan orang lain. Sikap kepatuhan anak pada pola asuh ini bersifat langsung karena bentuk dari asuhan ketat dan keras yang diterimanya (Benjet \& Kazdin, 2003).

Orang tua sebagai madrasah pertama anak, sebagai pemberi pendidikan awal kepada anak memiliki potensi dan kesempatan yang luas untuk membentuk dan memengaruhi anak pada masa awal perkembangannya, terdapat kesempatan untuk memfasilitasi, mendukung pembangunan karakter anak secara keseluruhan. Orang tua bertanggung jawab dalam memberikan dan menanamkan karakter dan nilai-nilai yang baik terhadapnya dengan pola pengasuhan yang tepat dan sesuai menurut perkembangan dan karakter anak.

\section{Pemberian Hukuman untuk Meningkatkan Karakter Disiplin pada Anak}

Banyak penelitian yang membuktikan berbagai keberhasilan dan kekurangan dari penerapan pola asuh bagi anak. Setiap orang tua jelas menginginkan anaknya menjadi anak yang patuh dan disiplin. Mukarromah, T, dkk, (2021) mengatakan bahwa disiplin sebagai salah satu bentuk pendidikan karakter yang diharapkan ada pada setiap anak. Dengan karakter disiplin anak dapat mengatasi masalah-masalah dan tercegah dari perbuatan yang kurang baik, melalui disiplin anak akan terbiasa dengan adanya peraturan, dapat belajar dan berperilaku sesuai kaidah di masyarakat sehingga dapat diterima dilingkungan sosialnya.

Orang tua dapat memberikan bentuk hukuman agar anak dapat lebih memahami dan sadar mengenai perbuatan yang kurang sesuai dengan tetap memberikan arahan-arahan, hukuman diberikan kepada anak sebagai suatu bentuk pendidikan dalam membentuk kepribadiannya (Yanuar, 2012). Pemberian hukuman hendaknya diberikan setelah tahapan pemberitahuan diberikan kepada anak lalu, memberikan teguran serta peringatan kepada anak, namun apabila belum terdapat perubahan setelah tahapan tersebut dilakukan maka dapat diberikan hukuman kepadanya. Sebagai catatan bahwa hukuman adalah cara paling akhir yang dilakukan untuk membentuk karakter disiplin pada anak. Penelitian mengenai pemberian hukuman yang bersifat edukatif ini pernah diterapkan oleh guru kepada muridnya oleh Dwiva \& Desni (2016) .

Pemberian hukuman kepada anak diharapkan dapat memperdalam pemahaman dan membuat anak lebih mengerti tentang nilai-nilai kedisiplinan untuk dirinya. Choirun (2013) dalam penelitiannya menerangkan bahwa hukuman merupakan bentuk dari nilai-nilai karakter disiplin yang diperlukan. Namun demi menerapkan kedisiplinan lalu menggunakan hukuman tidak dapat dibenarkan. Dengan menerapkan hukuman kepada anak maka diharapkan anak dapat mengetahui dan menghentikan perilaku yang salah, sehingga diwaktu mendatang anak dapat termotivasi untuk tidak mengulangi hal salah tersebut. Hukuman yang diberikan kepada anak dapat dipertanggung jawabkan apabila hukuman tersebut bernilai pedagogis dan pembelajaran sehingga dapat membantu anak menjadi mandiri dan dewasa (M. Ngalim Purwanto, 1992). 
Pola pengasuhan yang diterima anak akan mempengaruhi bagaimana anak bersikap terhadap berbagai bentuk dan sikap sosial yang diterimanya, baik itu pengasuhan yang membiarkan, demokratis ataupun otoriter. Pengasuhan yang keras dalam menanamkan nilai disiplin kepada anak dapat berakibat pada perilaku agresif dan akan menjadi contoh pengasuhan dan mengadopsi pola pengasuhan yang akan diulang kepada anaknya nanti, serta membuat anak cenderung bersifat agresif dalam mencapai tujuan-tujuan yang diharapkannya.

Dari penjelasan di atas dapat disimpulkan bahwa hukuman dan bentuk kekerasan yang diterapkan walaupun dengan dalih sebagai bentuk pendidikan dan pembelajaran kepada anak akan menimbulkan berbagai efek dimasa yang akan datang, kemudian hal tersebut memungkinkan anak mengadopsi pola yang sama. Setiap orang tua berhak menentukan pola pengasuhan yang tepat bagi anaknya. Pola pengasuhan yang baik dan tepat sesuai pada karakter anak harus dipertimbangkan oleh orang tua untuk diterapkan dengan sebaik mungkin agar anak menjadi pribadi yang baik dan unggul serta memiliki karakter dan kepribadian yang baik.

\section{SIMPULAN}

Pengasuhan yang baik dapat akan membawa dampak yang terbaik bagi perkembangan anak untuk itu orang tua sebagai orang yang paling bertanggung jawab terhadap perkembangan anak harus mempertimbangkan pola pengasuhan yang tepat untuk diterapkan kepada anak mereka. Gaya pengasuhan otoritatif atau demokrasi, permisif maupun otoriter masing-masing memberikan dampak yang berbeda-beda dan akan memberikan pengaruh pada perkembangan anak termasuk perkembangan karakter disiplin anak sebagai bekal dimasa mendatang.

\section{UCAPAN TERIMA KASIH}

Terima kasih penulis ucapkan kepada berbagai pihak yang membantu dalam penyelesaian artikel ini, serta terima kasih kepada tim Jurnal Obsesi yang telah memberikan kesempatan dan membantu perbaikan artikel sehingga dapat diterbitkan.

\section{DAFTAR PUSTAKA}

Anwar, S. (2016). Metodologi Penelitian. Salemba Empat.

Asiatik, R. A., Abdul, W. H., \& Chusnul, M. (2017). Smart Parenting Demokratis dalam Membangin Karakter Anak. Al-Athfal Jurnal Pendidikan Anak, 4(1), 1-16.

Aulina, C. N. (2013). Penanaman Disiplin Pada Anak Usia Dini. PEDAGOGIA: Jurnal Pendidikan, 2(1), 36. https:// doi.org/10.21070/pedagogia.v2i1.45

Benjet, C., \& Kazdin, A. E. (2003). Spanking children: The controversies, findings, and new directions. Clinical Psychology Review, 23(2), 197-224. https://doi.org/10.1016/S02727358(02)00206-4

Chatib, M. (2012). Orangtuanya ManusiaMelejitkan Potensi dan Kecerdasan dengan Menghargai Fitrah Setiap Anak. Kaifa.

Dahlena, W. (2019). Pengaruh Pola Asuh Orang Tua Terhadap Kedisiplinan Anak di TK Assalam 2 Sukarame Bandar Lampung. Universitas Islam Negeri Raden Intan Lampung.

Erik, E. (2010). Teori perkembangan psikosisial Erik Erikson.

Farzana Bibi, F. B. (2013). Contribution of Parenting Style in life domain of Children. IOSR Journal of Humanities and Social Science, 12(2), 91-95. https://doi.org/10.9790/08371229195

Hurlock. (1997). Psikologi Perkembangan: Suatu Pendekatan Sepanjang Rentang Kehidupan. Erlangga.

Husnul, B. (2016). Konsep tumbuh kembang dan kompetensi pendidikan anak usia dini. Penerbit Panda. 
DOI: 10.31004/obsesi.v5i2.985

Ida, W. (2019). Pola Asuh Orang Tua Dalam Meningkatkan Kedisiplinan Pendidikan Anak(Studi Deskriptif di Kelurahan Rabadompu Timur Kecamatan Raba Kota Bima). Jurnal Pendidikan Sosiologi, II(II), 43-49.

Juharta, Y. nur fatimah, Tjalla, A., \& Hidayat, dede rahmat. (2015). Belajar Dilihat Dari Pola Asuh Authoritative, Authoritarian Dan Permisif. insight jurnal, 4(1), 1-8. https://doi.org/10.21009/INSIGHT.041.18

Julie, A. (1996). Discipline. In Sourcebook Naperville (hal. 195).

Karmakar, R. (2015). Does Parenting Style Influence the Internalization of Moral Values in Childreen and Adolescents? Psycological Studies, 60(4), 438-446. https://doi.org/https://doi.org/10.1007/s12646-015-0338-2

Krisnawaty, T. (2010). Psikologi Keluarga. Griya Pustaka.

L.E.L, M. (2016). Child Development Form Infancy to Adolescene (An Active Learning Appeoach). SAGE.

Lasota, A. (2015). What do Children Learn from their Parents and what from their Grandparents? Changes in the Perception of Gender and Family Roles as Seen from the Developmental Perspective. Procedia - Social and Behavioral Sciences, 174. https://doi.org/Procedia - Social and Behavioral Sciences

Lia, P. A. D., \& Arif, R. (2021). Grandparenting membetuk karakter anak usia dini di masa pandemi covid-19. Jurnal Obsesi: Jurnal Pendidikan Anak Usia Dini2, 5(2), 1129. https://doi.org/10.31004/obsesi.v5i2.831

Lisa, D. R., Aswandi, \& Yuniarni, D. (2016). Penggunaan Hukuman yang Edukatif dalam Membentuk Perilaku Disiplin Anak di RA Babussalam. Jurnal Pendidikan dan Pembelajaran Khatulistiwa, 5(6), 1-10.

M. Ngalim Purwanto. (1992). Ilmu Pendidikan Teoritis dan Praktis Remaja Rosdakarya (Cet.21). Remaja Rosdakarya.

Martaniah, M. (1964). Peranan Orang Tua yang Berhasil. Jiwa Baru.

Mastura, S. R. \&. (2020). Dampak Pandemi Covid-19 terhadap Proses Pengajaran bagi Guru dan Siswa Pendahuluan. Jurnal Studi Guru Dan Pembelajaran, 3(2), 289-295.

Megawangi, R. (2004). Pendidikan Karakter: Solusi Tepat untuk Membangun Bangsa. Indonesia Heritage Foundation.

Mukarromah, T. T., Hafidah, R., \& Nurjanah, N. E. (2020). Kultur Pengasuhan Keluarga terhadap Perkembangan Moral Anak Usia Dini. Jurnal Obsesi : Jurnal Pendidikan Anak Usia Dini, 5(1), 395. https://doi.org/10.31004/obsesi.v5i1.550

Nauli, V. A., Karnadi, K., \& Meilani, S. M. (2019). Peran Ibu Pedagang Pasar 24 Jam Terhadap Perkembangan Moral Anak (Penelitian Studi Kasus di Kota Bekasi). Jurnal Obsesi: Jurnal Pendidikan Anak Usia Dini, 3(1), 3(1), 241-253. https://doi.org/https://doi.org/10.31004/obsesi.v3i1.179

Rahmi, Y. A., \& Riana, N. (2018). Pola Asuh Orang Tua untuk Meningkatkan Disiplin Anak. Jurnal Obor Penmas Pendidikan Luar Sekolah, 1(1), 3.

Ramadona, M., Anjani, A. R., \& Putriani, R. (2020). Pengaruh Pola Asuh Orangtua Terhadap Kedisiplinan Peserta Didik Di Smk Teknindo Jaya Depok. Research and Development Journal of Education, 6(2), 13. https://doi.org/10.30998/rdje.v6i2.4531

Riati, I. K. (2016). Pengaruh Pola Asuh Orang Tua Terhadap Karakter Anak Usia Dini. Jurnal Infantia, 4(2).

Sobur, A. (1991). Anak Masa Depan. Angkasa.

Steinberg, L., Blatt-Eisengart, I., \& Cauffman, E. (2006). Patterns of competence and adjustment among adolescents from authoritative, authoritarian, indulgent, and neglectful homes: A replication in a sample of serious juvenile offenders. Journal of Research on Adolescence, 16(1), 47-58. https://doi.org/https://doi.org/10.1111/j.1532-7795.2006.00119.x

Suyadi. (2014). Teori pembelajaran anak usia dini. PT Remaja Rosdakarya.

Tabi'in, A. (2017). Pengelolaan Pendidikan Karakter Disiplin Anak Usia Dini Studi Kasus Di Al-Muna Islamic Preschool Semarang. AWLADY: Jurnal Pendidikan Anak, 3(1), 2. 
https://doi.org/10.24235/awlady.v3i1.989

Walker, L. J., \& Hennig, K. H. (2010). Parenting Style and the Development of Moral Reasoning. Journal of Moral Education. Journal of Moral Education, 37-41. https://doi.org/https:/ / doi.org/10.1080/030572499103133

Wandi, Z. N., \& Mayar, F. (2019). Analisis Kemampuan Motorik Halus dan Kreativitas pada Anak Usia Dini melalui Kegiatan Kolase. Jurnal Obsesi : Jurnal Pendidikan Anak Usia Dini, 4(1), 363. https://doi.org/10.31004/obsesi.v4i1.347

Yanuar, A. (2012). Jenis-jenis Hukuman Edukatif untuk Anak SD.

Yenni, S. F. (2017). Penggunaan Model Pembelajaran Pendidikan Karakter Abad 21 pada Anak Usia Dini. Jurnal Obsesi: Jurnal Pendidikan Anak Usia Dini, 1(1), 52-61.

Z, M. (2014). Persamaan Model Pemikiran Al-Ghaza dan Abraham Maslow tentang Model Motivasi Konsumsi. UIN Suan Ampel Surabaya. 